\title{
PROTEOLYTIC ACTIVITY OF PHOSPHOROUS MOBILIZING BACTERIA OF BACILLUS GENUS AND THEIR INFLUENCE ON SOME PHYTOPHAGES
}

\author{
A. O. Roi, O. V. Matseliukh, P. D. Zubko, L. D. Varbanets, I. K. Kurdysh \\ Danylo Zabolotny Institute of Microbiology and Virology, NAS of Ukraine \\ 154, Akademika Zabolotnoho Str., Kyiv city DSP, D 03680, Ukraine e-mail: Kurdish@serv.imv.kiev.ua
}

\begin{abstract}
In vivo microorganisms synthesize
\end{abstract} hydrolytic enzymes that ensure the transformation of complex organic substances. Most of these enzymes are mainly hydrolases that affect proteins, lipids, polysaccharides and nucleic acids. The most common among these enzymes are extracellular proteases that are synthesized by various microorganisms, including bacteria of the Bacillus genus $[1 ; 2]$. It is shown that strains that synthesize extracellular hydrolytic enzymes with lipolytic, chitinolytic and proteolytic activity are able to penetrate the cells of plants and infect insects [3; 4]. Bacilli strains that we isolated from soil actively mobilize phosphorus from its soluble inorganic and organic compounds, are characterized by chitinolytic and antagonistic activity to pathogenic microorganisms, synthesize phenolic compounds and a number of other biologically active substances, make positive impact on the growth and development of floral, conifer and grass plants, as well as the yield of vegetable, grain and other crops [5-10].

The goal of the work is to determine the total proteolytic activity of phosphatemobilizing bacteria depending on culturing conditions and their impact on some phytophages.

Materials and methods. The objects of study were strains of phosphate-mobilizing bacteria isolated in the department of microbiological processes on solid surfaces of the Danylo Zabolotny Institute of Microbiology and Virology, NAS of Ukraine [5].

Bacteria were grown on gelatine medium of the following composition, $\mathrm{g} / \mathrm{l}$ : maltose - 1.0; gelatine - 10.0 ; $\mathrm{KH}_{2} \mathrm{PO}_{4}-1.6$; $\mathrm{MgSO}_{4}-7 \mathrm{H}_{2} \mathrm{O}-0.75$; $\mathrm{ZnSO}_{4}-7 \mathrm{H}_{2} \mathrm{O}-0.25$;
$\left(\mathrm{NH}_{4}\right)_{2} \mathrm{SO}_{4}-0.5$; yeast autolysate -0.15 ; pH 7.0-7.2 [11].

Mineral medium with glucose and glycerophosphate of the following composition $(\mathrm{g} / \mathrm{l})$ was used for comparison:

$$
\begin{aligned}
& \left(\mathrm{NH}_{4}\right)_{2} \mathrm{SO}_{4}-0.5 ; \\
& \mathrm{MgSO}_{4}-7 \mathrm{H}_{2} \mathrm{O}-0.3 ; \\
& \mathrm{NaCl}-0.3 ; \\
& \mathrm{KCl}-0.3 ; \\
& \mathrm{MnSO}_{4} 7 \mathrm{H}_{2} \mathrm{O}, \mathrm{FeSO}_{4}-0.001 ; \\
& \text { glucose }-10.0 ; \\
& \text { calcium glycerophosphate - } 2.0 ; \\
& \mathrm{CaCO}_{3}-5.0 ; \\
& \text { pH 7.0-7.2 }[5 ; 8] \text {. } \\
& \text { To determine the proteolytic activity }
\end{aligned}
$$
the cultivation of microorganisms was carried out in periodic conditions on a shaker $(220$ $\mathrm{rpm}$ ) at $28^{\circ} \mathrm{C}$ for two days in test tubes containing $20 \mathrm{ml}$ of medium.

The biomass was separated by centrifugation at $\mathrm{O \Pi H}(\mathrm{OPN})-8$ at $6600 \mathrm{~g}$ for $20 \mathrm{~min}$. Total proteolytic activity was determined in supernatant by Anson modified method [12]. The reaction mixture containing $0.5 \mathrm{ml}$ of the supernatant and $0.5 \mathrm{ml}$ of $1 \%$ casein $(\mathrm{pH}$ 7.0-7.2) was incubated for $30 \mathrm{~min}$ at $37^{\circ} \mathrm{C}$. The reaction was stopped by adding $1 \mathrm{ml}$ of $10 \%$ trichloroacetic acid. The precipitate was separated by centrifugation at $6600 \mathrm{~g}$ for $10 \mathrm{~min}$. $2.5 \mathrm{ml}$ of $0.5 \mathrm{~N} \mathrm{Na}_{2} \mathrm{CO}_{3}$ solution was added to $0.5 \mathrm{ml}$ of the supernatant was added and kept for 15 minutes; then $0.5 \mathrm{ml}$ of Folin reagent was added. 30 minutes later the optical density was measured at $\lambda=670 \mathrm{~nm}$ on a spectrophotometer CФ (SF) -46.

Proteolytic activity of bacilli supernatant was determined by the formula:

$$
\mathrm{PA}=\frac{\mathrm{D} \times 4}{\mathrm{TE} \times 30} \times 100
$$

where PA - proteolytic activity, $\mathrm{U} / \mathrm{ml}$; 
D - optical density;

4 - sample dilution factor;

TE - tyrosine equivalent (1.305);

30 - incubation time, minutes.

The unit of proteolytic activity corresponded to the amount of tyrosine $(\mu \mathrm{mol})$ released from the substrate within 1 min.

The suspensions of strains selected after 48 hours of growth in the medium with gelatine under regular cultivation conditions in Erlenmeyer flasks containing $50 \mathrm{ml}$ of the medium were used to investigate the influence of bacteria on phytophages. The number of viable cells in suspension was: $B$. pumilus $3-(6.1 \pm 1.0) \times 10^{9}$ cells $/ \mathrm{ml} ; B$. megaterium $2-(1.1 \pm 0.1) \times 10^{9}$ cells $/ \mathrm{ml} ; B$. subtilis IMB B-7023 - $(6.9 \pm 1.2) \times 10^{9}$ cells $/ \mathrm{ml}$. Experiments were conducted on two varieties of floral plants - coleus (Coleus blumei Benth) and zonal pelargonium (Pelargonium zonale), which are mostly damaged by phytophages: greenhouse whitefly (Trialeurodes voparariorum) and green peach aphid (Aulacorthum circumflexsus) [13].

The treatment of plants in the greenhouse was performed epiphytic with bacteria suspension on the upper and lower leaf surfaces. Initial bacteria suspensions were diluted with sterile tap water at a ratio of 1:100. The application standards for working suspension for epiphytic treatment were 7.0 $\mathrm{ml}$ per plant. Control plants (variant 1) were treated with the same volume of sterile water. In experimental variants plants were treated with suspensions $B$. pumilus 3 (variant 2 ), $B$. megaterium 2 (variant 3 ) and $B$. subtilis IMB B-7023 (variant 4). All experiments were conducted in three repetitions, each of which included 20 plants. Recording of phytophages was conducted on the $3^{\text {rd }}, 7^{\text {th }}, 10^{\text {th }}, 14^{\text {th }}, 16^{\text {th }}$ day. Separately the number of imago and maggots of phytophages (spec.) per 1 plant was calculated [13]. The calculation of the effectiveness of the bacteria suspensions influence on the number of phytophages was performed by the formula:

$$
E_{i}=\frac{A \times b-B \times a}{A \times a} \times 100
$$

where $E_{i}$ - effectiveness of the influence with allowance for control, \%;

A - the amount of phytophages in the experimental variant before the treatment spec./plant;

B - the amount of phytophages in the experimental variant after the treatment spec./plant;

a - the amount of phytophages in the control at the first recording spec./plant;

b - the amount of phytophages in the control at the following recordings spec./plant.

Statistical analysis of the results was carried out by Lakin [14].

So phosphate-mobilizing bacteria strains that exhibit proteolytic activity can influence the decrease in the number of phytophages and can be recommended for the treatment of coleus and zonal pelargonium plants, that are grown under conditions of covered soil. 